\title{
Improving the Thermal Fatigue Strength of Hot-Working Tools by Laser Treatment
}

\author{
Nikolai A. Chichenev ${ }^{1, a^{*}}$, Sergey M. Gorbatyuk ${ }^{1, b}$, Oleg A. Kobelev ${ }^{1,2, c}$ and \\ Aleksei N. Pashkov ${ }^{1,3, d}$ \\ ${ }^{1}$ National University of Science \& Technology (MISIS), Moscow, Russian Federation \\ 2 NPO TsNIITMAShl, Moscow, Russian Federation \\ 3 JSC "RPC "Istok" named after Shokin", Fryazino, Russian Federation \\ achich38@mail.ru, bsgor02@mail.ru, coakobelev@cniitmash.com, da.n.pashkov@yandex.ru
}

\begin{abstract}
Keywords: Hot-Working Die Steel, Thermal Fatigue, Laser Quenching, Laser Spot Diameter, Diameter of Laser Tracks
\end{abstract}

\begin{abstract}
A method for increasing the thermal fatigue strength of a tool used in hot forming of bearing rings by applying circular laser tracks to the working surfaces is considered. Laser treatment is carried out with a power of $2.0 \ldots 2.5 \mathrm{~kW}$ by applying on the end face working surface of the tool in the direction from the center to the periphery of the circular tracks with a common center coinciding with the center of the circumference of the end face; the tool is rotated at a constant angular rate, the spot diameter $\mathrm{d}_{\mathrm{s}}$ for each track is selected according to the dependence $\mathrm{d}_{\mathrm{s}, \mathrm{i}}+1 / \mathrm{d}_{\mathrm{s}, \mathrm{i}}=0.85 \ldots 0.90$, and the laser radiation spots of adjacent tracks have a common point of contact. The results of pilot testing are presented, which confirmed the high technical and economic efficiency of the use of laser quenching for ejectors and punches. A tool made by machining, for example, an ejector of an AMP-70 automatic press, is subjected to volume quenching and tempering. The ejector material was steel $3 \mathrm{Kh} 3 \mathrm{M} 3 \mathrm{~F}$, quenching temperature in oil $-1030 \ldots 1050{ }^{\circ} \mathrm{C}$, tempering temperature $-580 \ldots 610{ }^{\circ} \mathrm{C}$. After volume quenching, additional machining is carried out, usually grinding, in order to remove the decarbonized layer of material formed during heat treatment and to give the working surface the required roughness class. The final stage in the tool manufacturing is the quenching of its working surface by laser treatment. Pilot testing showed that the use of laser treatment made it possible to increase the durability of ejectors of various types by $2 \ldots 3$ times, of deforming punches - by 2.2 times.
\end{abstract}

\section{Introduction}

Hot forming methods using one of the important properties of metals, ductility, are widely applied in mechanical engineering due to the ability to produce parts of various sizes and diversified shapes in a highly productive and economical way [1-4]. The undoubted advantage of hot forming is that the resulting parts are characteristic of higher strength properties than similar parts made with metal-cutting machines. This is due to the peculiarity of the structure of the deformed metal in which the material fibers are located equidistantly to the part contour in hot forming, in contrast to the use of a metal-cutting tool in which the fibers are cut across. In addition, the productivity of hot forming is much higher than that of processing with metal-cutting machines; therefore, during serial and mass production, the prime cost of parts and metal losses is reduced tenfold.

The productivity of hot forming processes largely depends on the operational durability of the technological tool which fails mainly due to the heat of the working surface [5-7]. Therefore, steel used for manufacturing technological tools for metal hot working should not only have high mechanical properties at operating temperatures, but also have increased thermal fatigue strength. 
In the hot forming process, the temperature of the die is characterized by repeatedly changing heating and cooling, as a result of which the processes of thermal fatigue develop, accompanied by the appearance and development of hot cracks [8-10]. Theoretical and experimental studies have shown that the greatest increase in the durability of hot-working dies is achieved with the correct choice of the die steel grade and modes of its thermal and quenching treatment [11-13].

Heat treatment methods traditionally consisting of heating, holding and cooling not only have a limitation in the level of strength of heat-treated materials, but also have largely exhausted their possibilities in obtaining new structures and improving mechanical properties. A number of papers [14-20] shows that laser heat treatment is successfully used for surface quenching of parts and tools for various purposes, including working surfaces of a technological tool for processing materials by pressure. At the same time, the issues of laser thermal quenching of die steel $3 \mathrm{Kh} 3 \mathrm{M} 3 \mathrm{~F}$ (3X3M3Ф) widely used for manufacturing deforming tools operating at elevated temperatures are insufficiently presented for the development of technological modes of laser treatment. In some papers, the issues of laser quenching of die steel 4Kh5MFS (4X5MФC) with surface fusion are considered, which in some cases leads to an unacceptable deterioration of the surface morphology.

\section{Objective}

This article discusses a method for increasing the thermal fatigue strength of a tool used in hot forming of bearing rings by applying circular laser tracks to the working surfaces. The results of pilot testing are presented, which confirmed the high technical and economic efficiency of the use of laser quenching for ejectors and punches.

\section{Research carried out and analysis of the results obtained}

Tool steels of the martensitic class with carbide quenching of the type $3 \mathrm{Kh} 3 \mathrm{M} 3 \mathrm{~F}, 4 \mathrm{Kh} 5 \mathrm{MFS}$, etc. are used for manufacturing tools for hot forming, for example, ejectors and punches [21]. The main mechanism for quenching steels of this class is quenching for martensite and subsequent tempering, during which precipitation hardening occurs due to the release of alloying elements from the carbide matrix. Therefore, the properties of these steels are determined by the composition and structure of martensite and carbide phases, as well as the nature of the distribution of carbides and their interaction with the matrix. One of the most effective ways to increase the service life of a hot forming tool by increasing its heat resistance is to create a homogeneous finely dispersed structure on the working surface. An effective solution to this problem was obtained by using continuous laser radiation.

The results of metallographic analysis showed that the most effective grinding of the carbide phase is carried out when the tool material is exposed to continuous laser radiation with a power of $\mathrm{P}=2.0 \ldots 2.5 \mathrm{~kW}$ at power densities $\mathrm{q}=(3 \ldots .5) \mathrm{kW} / \mathrm{cm}^{2}$. At laser power values less than $2.0 \mathrm{~kW}$, the desired structural preparation is not effective enough, which can be explained by a weak thermal effect. At powers above $2.5 \mathrm{~kW}$, there may be a decrease in the steel impact strength, caused by a significant increase in austenite grain, which will lead to accelerated softening of the material during operation.

The scheme of a thermal laser effect on the flat circular surface is the most optimal, which is the application of circular tracks with a common center coinciding with the center of the circle, and each of the subsequent circular tracks adjacent to the previous one along a closed concentric line. Due to the fact that circular tracks are applied without gaps, the amount of the unhardened part of the surface is practically zero; in addition, due to the absence of overlapping tracks, there are almost no tempering zones. The alternation of pronounced tempering or unhardened zones 
causes surface structural heterogeneity of the tool material, which, as noted, causes accelerated tool wear.

Thus, the specified scheme of laser treatment under the condition $\mathrm{d}_{\mathrm{s}, \mathrm{i}}+1 / \mathrm{d}_{\mathrm{s}, \mathrm{i}}=0.85 \ldots 0.90$ provides a more uniform structure of the hardened layer and the axisymmetric distribution of residual stresses in the tool material.

The ratio $d_{s, i}+1 / d_{s, i}=0.85 \ldots 0.90$ was obtained experimentally; it can be justified as follows. Due to the fact that the purpose of laser treatment is to create the most homogeneous structure of the material, it is necessary that all the processed areas obtained by applying circular tracks have the same structure with a minimum difference in properties and form a generally homogeneous finely dispersed structure. Therefore, a prerequisite for laser treatment of a hot forming tool is that the energy contribution to the material must be the same for each of the circular tracks. However, at a constant angular rotation rate $\omega=$ const of the treated part with an increase in the radius $r_{t}$ of the circular tracks, the linear treatment rate $\mathrm{v}$ increases, which is equal to the product of the angular rate $\omega$ by the radius, i.e. $v=\omega \times r_{t}$. As experiments have shown, the diameter of the radiation spot should be changed according to the ratio $\mathrm{d}_{\mathrm{s}, \mathrm{i}}+1 / \mathrm{d}_{\mathrm{s}, \mathrm{i}}=0.85 \ldots 0.90$ when applying tracks in the direction from the center to the periphery in order to create the most homogeneous structure of the hardened near-surface layer due to the fact that the laser thermal effect is carried out at a constant value of the radiation power and, taking into account that when assessing the energy contribution of laser radiation, for example, to the maximum surface temperature, it is inversely related to the values of $\mathrm{d}_{\mathrm{s}}$ and $\mathrm{v}$.

The proposed method is carried out as follows. A tool made by machining, for example, an ejector of an AMP-70 automatic press, is subjected to volume quenching and tempering. The ejector material was steel $3 \mathrm{Kh} 3 \mathrm{M} 3 \mathrm{~F}$, quenching temperature in oil $-1030 \ldots 1050{ }^{\circ} \mathrm{C}$, tempering temperature $-580 \ldots 610^{\circ} \mathrm{C}$. After volume quenching, additional machining is carried out, usually grinding, in order to remove the decarbonized layer of material formed during heat treatment and to give the working surface the required roughness class (Fig. 1).

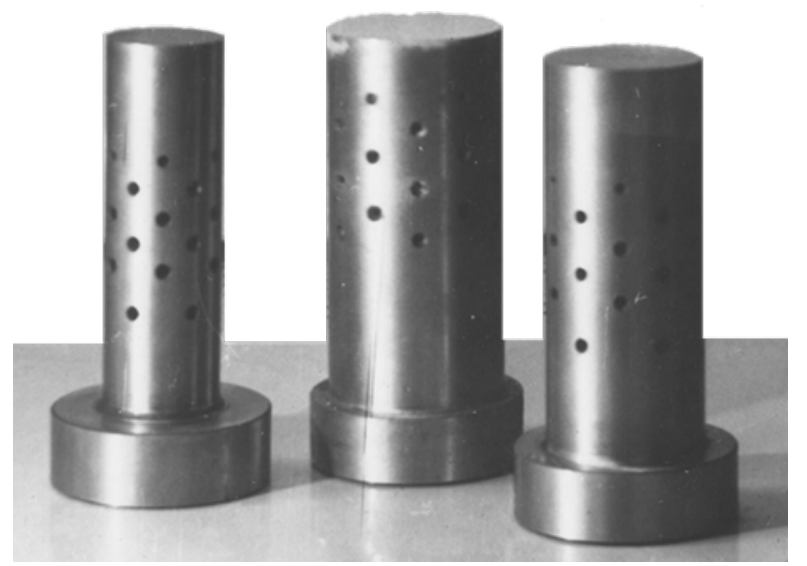

Fig. 1. Examples of ejectors used for forming of bearing rings of various sizes

The final stage in the tool manufacturing is the quenching of its working surface by laser treatment which is carried out as follows. To increase the efficiency of laser radiation absorption by the metal, a light-absorbing coating 10-15 $\mu \mathrm{m}$ thick, for example, blue zinc gouache, is applied to the working surface of the tool. Then the tool is mounted in a manipulator capable of rotational movement, and it is possible to translocate the rotational movement in the horizontal and vertical planes. 
After starting the laser installation, a specific value of the laser radiation power should be set, which is included in the specified interval. The ejectors were treated with laser radiation with a power of $2.1 \mathrm{~kW}$ using a $\mathrm{CO}_{2}$ laser. Having established the required radiation power using a power meter, the laser beam is focused until the desired spot diameter $d_{s}$ is obtained on the end surface of the tool fixed in the manipulator. The spot diameter $d_{s}$ and the angular rotation rate $\omega$ of the treated part are chosen so that the laser treatment is carried out without surface fusion. The initial diameter of the laser radiation spot when treating the ejectors was $d_{s, 0}=10 \mathrm{~mm}$, while $\omega=0.31 \mathrm{~s}^{-1}$.

By longitudinal translocation of the tool relative to the focused beam, the radiation spot is set on the surface so as to apply the first circular track of the minimum radius relative to the center of the circumference of the end face of the cylindrical part, while the radius of the circular track is considered to be the distance from the specified center to the center of the radiation spot. Experiments have shown that it is advisable to take the radius of the first circular track equal to the initial diameter of the focused spot on the treated surface, i.e. $r \operatorname{tr}, 1=d_{s}, 0$. When treating ejectors, the initial spot diameter is $d_{s, 0}=8 \ldots 10 \mathrm{~mm}$.

After turning on the rotating manipulator and the laser, a thermal effect on the laser radiation material is carried out by applying a circular track, the width of which is determined by the spot diameter. Then, the spot diameter is determined using the ratio $d_{s, i}+1 / d_{s, i}=0.85 \ldots 0.90$, at which the next circular track will be applied; focusing is carried out. Focusing of each next spot is easily done either with a lens or by translocating the tool in a vertical plane. By longitudinal translocating of the tool before applying the next circular track, the focused spot is set so that it has a common point of contact with the previous circular track. The latter operation is facilitated by the fact that the boundaries of the circular heat-affected zone are clearly marked by the burnt-out absorbing coating.

Circular tracks are applied until the working surface is completely treated. Thus, for a tool with a diameter of $65 \mathrm{~mm}$, laser treatment of the working surface is carried out by applying three circular tracks with a spot diameter equal to $d_{\mathrm{s}, 1}=10 \mathrm{~mm}, d_{\mathrm{s}, 2}=9 \mathrm{~mm}$ and $d_{\mathrm{s}, 3}=8 \mathrm{~mm}$ respectively; the radius of the first track is equal to $r_{t, 1}=10 \mathrm{~mm}$, the second $-r_{t, 2}=19.5 \mathrm{~mm}$, the third $-r_{t, 3}=28$ mm (Fig. 2).

The proposed method has passed pilot testing in the manufacture of a working tool of an automatic press, designed for forming bearing rings 7608 (Table 1). The most worn-out element of die tooling is ejectors, the main reason for the rejection of which is hot crack formation. As a result of manufacturing and quenching of ejectors according to the proposed method, a threefold increase in durability was achieved and, therefore, the service life of the tool increased by an average of 3 times. Experiment planning methods were used in the research [22-25].

Pilot testing of the developed technology of laser quenching of working surfaces of hot deformation dies was carried out in the conditions of the forging shop of the bearing plant.

The quenching treatment was carried out using a continuous $\mathrm{CO}_{2}$ laser. Ejectors and punches were previously subjected to volume heat treatment in the thermal section of the forging shop, including quenching from a temperature of $\mathrm{T}=1050 \ldots 1100{ }^{\circ} \mathrm{C}$ in oil and tempering at a temperature of $\mathrm{T}=580 \ldots 610^{\circ} \mathrm{C}$; as a result, the hardness of the working surface of the tool was HRC 46...48. 


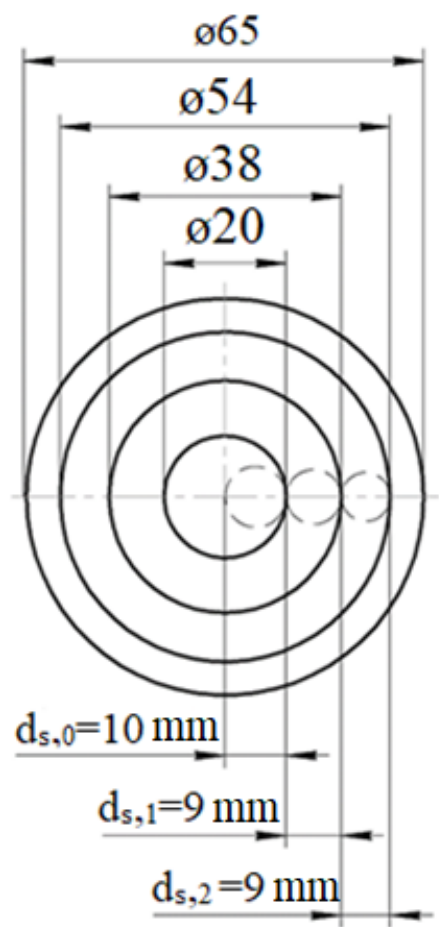

Fig. 2. Scheme of applying circular tracks on the working surface of the ejector with a diameter of $65 \mathrm{~mm}$

Table 1. Dependence of the thermal fatigue resistance of the tool on the ratio of the diameters of the radiation spot

\begin{tabular}{|c|c|c|}
\hline \multirow{2}{*}{$\begin{array}{c}\text { The ratio of the diameters of the } \\
\text { radiation spot, } \\
\mathrm{d}_{\mathrm{sp}, \mathrm{i}+} 1 / \mathrm{d}_{\mathrm{sp}, \mathrm{i}}\end{array}$} & $\begin{array}{c}\text { Theres until the first cracks } \\
\text { appear }\end{array}$ & $\begin{array}{c}\text { Average service life of } \\
\text { the ejector, forgings }\end{array}$ \\
\cline { 2 - 3 } No laser treatment & 1300 & 9600 \\
\hline 1 & 2900 & 22000 \\
\hline 0.9 & 4100 & 29500 \\
\hline 0.85 & 3900 & 29100 \\
\hline 0.8 & 3100 & 25300 \\
\hline 0.7 & 3000 & 23400 \\
\hline
\end{tabular}

Pilot testing showed that the use of laser treatment made it possible to increase the durability of ejectors of various types by $2 \ldots 3$ times, of deforming punches - by 2.2 times. In laser treatment of punches, circular tracks were applied to the working surface by rotating the punch around its axis.

Since the number of thermal fatigue cracks in the laser-hardened tool is significantly lower compared to the tool treated according to the traditional technology, the possibility of reusing the worn-out die (ejectors and punches) has been tested. The defective layer determined by the depth of development of hot cracks was mechanically removed from the surface of laser-hardened wornout ejectors, which had already shown a threefold increase in resistance. After grinding, the working surfaces were treated with laser radiation, while preliminary volume heat treatment was 
not required, and the ejectors were returned to operation. As a result of the tests, it was found that the durability of ejectors re-treated with laser radiation was twice as high as the durability of the new tool subjected to volume heat treatment according to the plant technology. It has been shown that such an operation can be performed 2 to 4 times.

In total, according to the developed technology, 580 units of working tools for hot forming of bearing rings on an AMP-70 automatic press in the conditions of the forging shop of the bearing plant were processed and tested in industrial conditions. The test results and statistical data confirmed the high technical and economic efficiency of the use of laser quenching for ejectors and punches, while the annual savings are achieved both by increasing the operational reliability of the tool and by extending the service life of the tool due to repeated sets and a decrease in the production of defective forgings.

\section{Summary}

A method is proposed for increasing the thermal fatigue strength of a tool used in hot forming of bearing rings by applying circular laser tracks to the working surfaces. Laser treatment is carried out with a power of $2.0 \ldots 2.5 \mathrm{~kW}$ by applying on the end face working surface of the tool in the direction from the center to the periphery of the circular tracks with a common center coinciding with the center of the circumference of the end face; the tool is rotated at a constant angular rate, the spot diameter $d_{s}$ for each track is selected according to the dependence $d_{s, i+1} / d_{s, i}=0.85 \ldots 0.90$, and the laser radiation spots of adjacent tracks have a common point of contact. Pilot testing showed that the use of laser treatment made it possible to increase the durability of ejectors of various types by $2 \ldots 3$ times, of deforming punches - by 2.2 times. The possibility of reusing a worn-out die (ejectors and punches) by removing the defective layer with subsequent laser treatment of the working surface is shown.

Taking into account the high technical and economic efficiency of the use of laser quenching for ejectors and punches, it is planned to apply the developed approach for another die for hot deformation [26-30].

\section{References}

[1] Kovka i shtampovka: spravochnik. V 4 t. T. 2 Goryachaya ob"emnaya shtampovka / Pod obshch. red. E. I. Semenova. - M.: Mashinostroenie, 2010. - 720 s.

[2] Titov Yu. A., Kokorin V.N., Morozov O.I. Tekhnologiya kovki i ob"emnoi shtampovki: uchebnoe posobie. - Ul'yanovsk: UlGTU, 2016. - $111 \mathrm{~s}$.

[3] B. K. Konstantinov. Tekhnologiya kovki i goryachei ob"emnoi shtampovki: uchebnoe posobie. - M. : NITs INFRA-M, 2019. - $104 \mathrm{~s}$.

[4] E. I. Semenov. Kovka i goryachaya shtampovka: uchebnik. - M. : MGIU, 2011. - 414 s.

[5] A. Steniko, V. Tami. Sovershenstvovanie protsessa pryamoi zakalki na zavode kompanii Nucor Tuscaloosa. Chernye metally. 2018 № 12 s. 41-43.

[6] D. I. Vasil'ev, M. A. Tylkin, G. P. Teterin. Osnovy proektirovaniya deformiruyushchego instrumenta. - M.: Vysshaya shkola, 1980. - 223 s.

[7] Ya. M. Okhrimenko, L. I. Antonenko, L. I. Mironov. Shtampy dlya goryachei obrabotki metallov i ikh ekspluatatsiya. - M.: Mashinostroenie, I971. - $50 \mathrm{~s}$.

[8] V. A. Korotkov. Issledovanie stoikosti shtampovogo instrumenta iz stali 5KhNM // Byul. «Chernaya metallurgiya». - 2010. - № 3-s.72-76. 
[9] Shtampy dlya goryachego deformirovaniya metallov/ pod obshch. red. M. A. Tylkina. - M.: Vysshaya shkola, 1977. - $496 \mathrm{~s}$.

[10] S. N. Aqida, F. Calosso, D. Brabazon, S. Naher, M. Rosso. Thermal fatigue properties of laser treated steels. Int. J. Mater. Form. 2010. № 3. pp. 797-800. https://doi.org/10.1007/s 12289010-0890-1

[11]A. E. Smirnov. Upravlenie fazovym sostavom kompleksno-legirovannykh teplostoikikh stalei pri vakuumnoi tsementatsii i zakalke // Metallovedenie i termicheskaya obrabotka metallov. 2020 .- № 9(783) .- s. 45 - 52.

[12] G. V. Levchenko, S. B. Bobyr', E. G. Demina, S. A. Zdorovets, Ya. Yu. Yakimenko. Vliyanie mikrolegirovaniya na strukturu i termotsiklicheskuyu stoikost' nizkolegirovannykh shtampovykh stalei // Metaloznavstvo ta termichna obrobka metaliv. 2008. № 1. s. 51-57

[13]A. B. Akinin, S. V. Boev. Povyshenie stoikosti chekanochnogo instrumenta iz stali Kh12MF provedeniem zakalki v azote vysokogo davleniya i termotsiklirovaniya // Metallovedenie i termicheskaya obrabotka metallov. 2020. № 2 (776). s. 31 - 36

[14]N. Maharjan, W. Zhou, Y. Zhou, N.Wu. Underwater laser hardening of bearing steels. Journal of Manufacturing Processes. 2019. Vol. 47, pp. 52-61. https://doi.org/10.1016/j.jmapro.2019.08.020

[15] A. Khorram, Jamaloei A.Davoodi, A. Jafari, M .Moradi. Nd:YAG laser surface hardening of AISI 431 stainless steel; mechanical and metallurgical investigation. Optics and Laser Technology. 2019/ Vol. 119, Article № 105617. https://doi.org/10.1016/j.optlastec.2019.105617

[16] Balajaddeh M. Bahrami, Moosavy H. Naffakh. Pulsed Nd:YAG laser welding of 17-4 PH stainless steel: Microstructure, mechanical properties, and weldability investigation. 2019. Optics and Laser Technology. Vol. 119, article № 105651.

https://doi.org/10.1016/j.optlastec.2019.105651

[17] S. G. Gornyi, Yu. B. Grechko, M. I. Patrov, K. V. Yudin, V. I. Yurevich. Lazernaya markirovka materialov // Fotonika, 2007. № 3. s. 16-22.

[18] T. Dikova. Surface modification of 3Ch2W8F and 4Ch5MFS steels by CO2 laser // J. of the Technical University at Plovdiv "Fundamental Sciences and Applications". 2006. Vol. 13 (7). pp. 81-90.

[19] Ho Jun Shin, Young Tae Yoo. Microstructural and hardness investigation of hot-work tool steels by laser surface treatment // J. of Materials Processing Technology. 2008. Vol. 201 pp. 342-347. https://doi.org/10.1016/j.jmatprotec.2007.11.232

[20] V. V. Morozov, A. N. Shlegel', A. V. Aborkin. Empiricheskie modeli lazernogo uprochneniya rabochikh kromok detalei formovykh komplektov stekloformuyushchikh mashin // Fundamental'nye i prikladnye problemy tekhniki i tekhnologii. 2011. № 2 (286). s. 79-84.

[21] Marochnik stali i splavov. http://splav-kharkov.com/mat_start.php?name_id=287 (data obrashcheniya 24.02.2021).

[22] V. A. Lunev. Matematicheskoe modelirovanie i planirovanie eksperimenta: uchebnoe posobie. - SPb.: Izd-vo SPbGPI, 2012. - $153 \mathrm{~s}$.

[23] Yu. A. Makarichev, Yu. N. Ivannikov. Metody planirovanie eksperimenta i obrabotki dannykh: uchebnoe posobie. - Samara: Samar. gos. tekhn. un-t, 2016. - 131 s. 
[24] N. I. Sidnyaev. Teoriya planirovaniya eksperimenta i analiz statisticheskikh dannykh : uchebnik i praktikum dlya vuzov. - M.: Izdatel'stvo Yurait, 2019. — 495 s.

[25]N. A. Chichenev, S. M. Gorbatyuk, M. G. Naumova; I. G. Morozova. Using the similarity theory to describe laser hardening processes. CIS Iron and Steel Review. 2020. Vol. 19. pp. 4447. https://doi.org/10.17580/cisisr.2020.01.09

[26]A. G. Grigor'yants, I. N. Shiganov, A. I. Misyurov. Tekhnologicheskie protsessy lazernoi obrabotki: Uch. posobie. - M.: Izd-vo MGTU im. N. E. Baumana, 2006. - 663 s.

[27] Lazernye tekhnologii obrabotki materialov: sovremennye problemy fundamental'nykh issledovanii i prikladnykh razrabotok / Pod red. V. Ya. Panchenko. - M.: FIZMATLIT, 2009. $664 \mathrm{~s}$.

[28] I. A. Pinakhin, V. A. Chernigovskii. Osnovy ob"emnogo impul'snogo lazernogo uprochneniya instrumental'nykh i konstruktsionnykh materialov [Elektronnyi resurs]: monografiya. - Stavropol': izd-vo SKFU, 2014. - 160 s. Rezhim dostupa: https://rucont.ru/efd/304170.

[29] Eron'ko, S.P., Oshovskaya, E.V., Tkachev, M.Y. Fast replacement of submersible tundish nozzles in a continuous slab-casting machine (2016) Steel in Translation, 46 (1), pp. 33-38. https://doi.org/10.3103/S0967091216010034

[30] A. V. Aborkin, V. E. Vaganov, A. N.Shlegel', I. M. Bukarev. Effect of laser hardening on die steel micro hardness and surface quality // Metallurgist. 2015. T. 59. № 7-8. s. 619-625. https://doi.org/10.1007/s11015-015-0148-8 